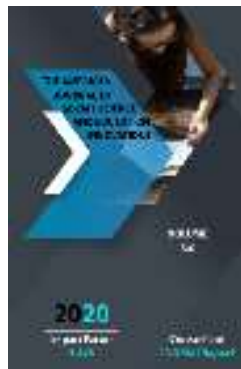

Journal Website: http://usajournalshub.c om/index,php/tajssei

Copyright: Original content from this work may be used under the terms of the creative commons attributes 4.0 licence.

\section{Technological Fundamentals Of Creating Interactive Electronic Courses}

\author{
M. Usmonov \\ Senior Teachers Of Jizzakh State Pedagogical Institute, Uzbekistan \\ H. Shukurova \\ Senior Teachers Of Jizzakh State Pedagogical Institute, Uzbekistan \\ B. Suvonqulov \\ Senior Teachers Of Jizzakh State Pedagogical Institute, Uzbekistan
}

\title{
ABSTRACT
}

This article describes the importance and technological basics of interactive e-learning in today's educational process. Furthermore, the opportunity to use interactive e-learning courses for the learning process in remote education is highlighted.

\section{KEYWORDS}

Interactive, distance learning, educational process, electronic course.

\section{INTRODUCTION}

Today's demand is to reform the educational process in the education system, to develop teaching methods based on new information technologies, their widespread introduction. At the same time, the introduction of interactive e-learning courses in the educational process is becoming one of the requirements of the times. 


\section{MATERIALS AND METHODS}

It should be noted that programmers and system tools should be taken into account when creating interactive e-learning courses (IEOs) for the learning process. The following is a list of features that should be available in educational computer programs:

For the user:

1. Organization of the learning process at different levels from familiarization to full mastery;

2. Opportunity to present educational materials depending on the purpose of training;

For the programmer:

1. Give the identified consistency in the program;

2. Make a list of concepts that are difficult to understand;

3. Create a graphical model of the relationship between mutually defined concepts.

Distance learning $(D L)$ is a method of distance learning based on new information and communication technologies - e-mail, Internet, video conferencing, audio, video data and multimedia IEOs. In this way, information on a new topic or subject can be remotely transmitted to voluntary educational institutions in the regions.

\section{RESULT AND DISCUSSION}

Primary model. In this form of distance learning, it is not necessary to conduct direct training in the full-time department, all training is organized at a certain distance. But learners are in constant contact with the teachers attached to it. Local representatives will be set up to provide counseling and final examinations to the students. In this case, the forms and methods of the educational process are freely chosen by the student, the schedule of classes and teaching time is not limited. Most open universities are built on a basic model of teaching, for example, this model of distance learning is used at an open university in the UK (http://www.open.ac.uk).

- Secondary model. Education in an educational institution is carried out both in full-time education and in parttime and part-time distance education. In both, the course schedule and curriculum are the same.

- $\quad$ For learners, control is assessed based on the same criteria. This secondary model of distance learning used in an educational institution is not always useful, as the bulk of the training is covered by the learners. For example, the secondary model is used in Australian universities (http://www.une.edu.au).

- Mixed model. This model covers different forms of teaching, or rather the integration of different subjects, for example, learners receive a certain part of the learning material in series with distance learning, the other part in parallel through full-time direct learning. Some classes are held in the form of virtual seminars, demonstrations (presentations), lectures. As long as the educational institution is equipped with information and communication technologies, the forms of teaching can be organized in different ways. These integrated forms of teaching are used at Massey and New Zealand universities (http: // massey. Ac. Nz).

- Consortium. This model is based on the interaction of two educational institutions, i.e. the production of teaching materials and the interdependence of certain functions 
in their distance learning. While the first institution develops training materials for distance learning, the second institution provides training tools for virtual learning groups or the implementation of a distance learning program.

- $\quad$ The consortium will deliver effective results with strict central management, private property and copyright provided in the prescribed manner.

- This model of teaching is used, for example, in the Canadian Open Learning Agency (http://www.ola.bc.ca).

- $\quad$ Franchising. In this model, which is based on the franchising principle of teaching, communicative educational institutions exchange distance courses created by each other. An educational institution that owns a product that is recognized as good in the market of educational services provides training courses created by other educational institutions, or is conducted through training. A characteristic feature of this model is that a student who intends to study at a particular educational institution will have the opportunity to receive a diploma of the same size, but high quality knowledge and at the end of study, through a consortium of mature higher education institutions.

- Validation. this model of teaching is one of the most common forms of teaching. All educational institutions in contact shall enter into an agreement on distance learning on an equal basis. Together, they create a distance learning program and course, and the diplomas and certificates awarded are equally recognized. A distant audience. In this model, modern information and communication technology tools are widely used. Training courses, lectures and seminars organized in a particular educational institution are broadcast on telecommunication channels in the form of synchronous television, video conferencing, radio communication to remote auditoriums where students are gathered. In this situation, the teacher works with a large audience of students. This model of teaching is used at the University of Wisconsin in the United States, as well as at the Central University of Radio and Television in China.

Projects. This model of training is used in the implementation of large-scale projects of national importance. The main role in this model is given to the scientific-methodical center, which gathers qualified personnel, teachers, scientists who create teaching materials. The distance courses created at the center will be presented to a large audience of a country. In it, training is seasonal and ends only when the goal is achieved. An example of this distance learning course is an introduction to new agro-technical methods related to ecology and agriculture. The design model of distance learning is widely used in international organizations of developing countries in Africa and Latin America.

- There are three problems in the introduction of the education system:

- $\quad$ Technical: provision of computers and technical devices, occupation of communication channels.

- Organization: provision of highly qualified managers, teachers, specialists. 
- Methodical: providing visual aids, lecture text, multimedia, animation, test data.

- $\quad$ There are a number of advantages and benefits to using it in education, including:

- $\quad$ Study time is optional, the student can study at any time.

- Classes do not have to be in the classroom.

- Teaches students to practice independently.

- $\quad$ Requires high training from teachers.

- $\quad$ Students can gain practical and quality knowledge.

- $\quad$ Students develop the ability to think independently and make decisions.

- $\quad$ Students develop the ability to use technical devices, computers, Internet, e-mail systems.

- The cost of education is cheap. New conditions will be created for the education of talented young people, especially from low-income families.

- $\quad$ Education does not choose borders, ie students can study in other places - in the region, in the city.

There are specific elements of the learning process, which are the instructor (teacher), students, communication, teaching materials, devices. Bunda:

- Instructor, teacher - this is a special specialist, a teacher. He prepares the relevant course, advises students, listeners, answers questions, monitors students' knowledge.

- Study material - is a relevant course, textbook, Internet, electronic library.

- A student is a person who increases his knowledge through MT, receives the necessary information, he is engaged independently, asks questions, performs assigned tasks, checks his knowledge.
- Communication is a means of communication, a bridge between the instructor and the student. It can also act as a link between student and student.

For this purpose, searching for the necessary information from an e-book or copying it to edit a text, and for such purposes, not only makes it cheaper to collect information, but also provides the opportunity to turn the data into a book.

Many companies are currently engaged in the sale of interactive e-learning courses for distance learning. Their main goal is to organize a certain form of electronic market and get the necessary benefits in it. Several programming languages are currently used to create such tutorials. In particular, Macromedia Flash, Microsoft FrontPage, Microsoft PowerPoint, HTML, JavaScript, CSS, PHP and similar programming languages, JSP and other programming technologies are used. Such programming languages allow you to view a certain amount of documents over the Internet. They can be used to organize text, images, various references to a web page. Of course, JavaScript has more capabilities than HTML when creating such programs. It can be used to place active elements on a web page. It is also possible to use only HTML software when creating an IEO. Through this language it is possible to create the base part of the IEO, the text of the questions, the answer options, and so on. HTML programming language is one of the only languages that allows you to view documents on the Internet.

The main features of choosing a JavaScript programming language are:

a) JavaScript is very easy to work with HTML documents;

b) The active and passive parts of the program are located in one document. JavaScript is a program that interprets the 
loading of a particular program in a web browser. This increases the performance and download speed of the configured program, and no special software is required to download it, other utilities will be located in the browser itself.

c) A JavaScript program can run in all web browsers just like a Java program, but it is easier and more convenient to create a program in JavaScript than in Java.

\section{CONCLUSION}

It is also possible to use the CGI interface when setting up a self-management system, but without a bus it would never be possible to use a self-management system on a local network. That is why the JavaScript programming language was chosen. Adobe Photoshop7.0 is used to create, optimize, and edit GIF and JPG files used in IEOK. This program is used to collect and edit promotional images, process some images, add colors.

In short, the information-educational tools created are widely used in distance learning systems as a traditional form of education for students. The developed teaching materials increase the level of independent work for fulltime students and at the same time do not impose much difficulty for the teacher. Currently, the creation of e-learning manuals that meet some of the principles and requirements of the above-mentioned IEOC is important in the distance learning process.

In our research, the above possibilities have been considered, albeit incompletely. For other programs that are based on this program, some of the user's options may be considered.

\section{REFERENCES}

1. Polat E.S. Distance learning: organizational and pedagogical aspects. INFO, 1996, No. 3.

2. Polyakov A.A. Distance learning systems // New knowledge, 1996, no. 3, -p. 34-35.

3. Taylaqov N.I. Models and forms of distance

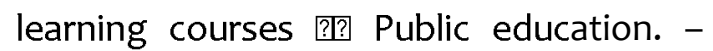
2004. -№2. -p. 85-89.

4. Taylaqov N.I. Prospects for the introduction of distance learning in the system of continuing education of the Republic. International Scientific and Practical Conf. "The use of the Internet in the educational process." Thesis. dokl. Moscow - Tashkent. -2002. p. - 42-43.

5. Usmonov $M$. Development of training courses in a multimedia environment. Materials Mezhzonalnoy nauchnoteoreticheskoy konferensii Talented students "Youth and modern techniques and technologies" Jizzakh March 28-29, 2008. 370 p. Jizzax. 2008, 322-324 p. 